\title{
THE IMPLEMENTATION OF REWARD AND PUNISHMENT TOWARDS STUDENT PERCEPTION IN ENGLISH LEARNING AT IKIP SILIWANGI
}

\author{
Yusi Amalia Sri Wantina ${ }^{1}$, Dhea Widya ${ }^{2}$ \\ ${ }^{1}$ IKIP Siliwangi \\ ${ }^{2}$ IKIP Siliwangi \\ 1yussiamalliasw@gmail.com, ${ }^{2}$ dheawidya03@gmail.com
}

\begin{abstract}
This Research titled THE IMPLEMENTATION OF REWARD AND PUNISHMENT TOWARD STUDENTS' PERCEPTION IN ENGLISH LEARNING AT IKIP SILIWANGI aimed to investigate the students'perception of reward and punishment and analyze the positive effect to student. This study imployes a qualitative reseach and the strategy used in this reseach is descriptive qualitatiave. This research took place at English Education Department Program IKIP SILIWANGI by involving interview college students at two classes randomly. The finding of this research is students'perception of reward and punishment. the students who proper to get a punishment when the students do not do the assignment, coming late etc. and the students who proper to get the reward when the students can answer the questions and also get additionl score. they can get B score for someone always present in every meetings, but it depend on the individu in order to do not repeat the mistake that they have done so obviously giving a reward can motived the student in learning activity because the students will to compete to get that reward.
\end{abstract}

Keywords: Perception, Rewards and punishment, Students' response and students' understanding

\section{INTRODUCTION}

Students motivation affects in every aspect of school life, attendances, academic performance, and extra-curricular activities. Parmawati (2018) states that Literacy level in learning activities are performation, functional, informational, and epistemic. Students with learning activity get greater challenge every day as they are in the classrooms because those can struggle with the tasks presented by teachers. Students can be seem like the most unmotivated of all and going to extremes to show their weaknesses.

In this research, perception refers to combination of effort plus desire to achieve the goal of learning the language plus favorable attitudes towards learning the language. The quantity and the quality of teacher-student interaction are affected by the communication climate in the classroom (Balliet \& Mulder, 2011). When rewards are given by teacher, students do not perceive themselves in control of learning, their approach and complete tasks differently than when rewards are not given, and their work is judged as less creative.

The punishment implemented by the teacher is to motivate the students to be better, make them discipline and reduce their negative behavior. As well as reward and punishment strategies also showed by diverse student responses. As we know that implementation both of punishment and reward as a method to prevent any violation and to appreciate achievement which is gotten by hard effort in learning individually or together. 


\section{Volume 2, No. 6, November 2019 pp 776-782

The implementation of reward and punishment was conducted in English Language learning activities to find out how reward and punishment implemented especially in English classroom learning activities. Although this approach is often characterized as focusing primaliry on reward and punishment the center actually place great emphasis on "catching student being good" and then providing appropriate feedback and reinforcement (Langa, 2014)

During the researcher observed at English Education Departement, most of the students seemed to be less motivated to learning. Most of them thought English as a difficult subject.(Riswanto, Java, \& Entrepreneurs, 2017) serendipitously found that requiring the students to explain their design decisions dramatically and beneficially altered their understanding of course materials. They did not follow the lesson well especially when the teacher explained about anything related grammar, they found it difficult to remember the words and they were discouraged to speak all about with English.

Reward and punishment have the same purpose to reinforce the achievement students independent learning. Reward has the purpose to make students more eager to improve and enhance their achievement. The application reward by teacher must follow principle (Langa, 2014).- puposes must be strengthened on a short term basis, so that the pulpil can make connection between the behavior wished from it and the strengthening. - rewards must be in time and not with delay. - the granting of reward may be made for a set of action or content.

Reward has been become interfere between the quality of learning taking place and the choices students make about their own learning. They need to practice with other students in the classroom. They develop competency and become critical thinkers in classroom that provides opportunities for intensive, structured interaction among students (Bishop, 2000). To make the most of educational potential, a student must continually challenge himselves to new and more difficult tasks, therefore increasing his learning. The type amount of a reward have an effect on motivation and performance. The punishment is given by teacher with the objectives what they doing. In applying a punishment, the following aspect show by taken into account (Langa, 2014)

a. Prevention of avoidance of punishment by specifying to the step necessary to re-win privilages.

b. Use of the warning upon the first deviation, the pulpil shall receive a warning, upon a second deviation some privilages shall be with drawn and if it continues shall be punished

The research focused on what kinds of reward and punishment that the teacher implemented and what responses that the students gave to reward and punishment strategies that were implemented by the teacher. The more the input is queried, recycled and paraphrased, to increase its comprehensibility, the greater its potential usefulness as input (Mitchell et al., n.d.). In this case of less motivated intrinsically, the students may be more extrinsically.

\section{METHOD}

The study consists of the basic qualitative research. According (Engineering, Prof, Air, \& Padang, 2014) basic qualitative research as seeking an understanding of what a phenomenon means to those participating in it, using in depth interview, observation and 
document reviews. Interviews are particularly useful for getting the story behind a participant experiences. The interviewer can pursue in-depth information around the topic. Interviews may be useful as follow-up respondents to questionnaires, e.g., To further examine their responses. (Price, 1977). The data here are the results of interviews with fourth-level students in Ikip Siliwangi. The interview depelove by research was used for data collection. The participant in this study are at IKIP SILIWANGI.

The instrument used in this research were interview, field questionaire, the questionnaire used to the student on interview the interview consist given 13 question, the method section should be brief should include sufficient technical information to allow the experiments to be repeated by a qualified question. Only new methods should be described in detail.

\section{RESULTS AND DISCUSSION}

\section{Results}

In this study, data taken as many as 8 data from sample the results of student using the's opinion used interview. Based on document analysis of the Implementation of rewards and punishment towards students perception the researcher got the result:

\section{Data 1}

Based on the first participant, he stated the placement of punishment and reward in classroom should be done fairly and a award given to the student who had followed the course rules. The example of punishment giving in the learning process is if in one of group could not do their presentation when their turned, other groups did not gave tolerance because it would obstruct them. One another hand, the rewards is given to the student who had follow the course. The lecturer would give point plus as award if the student could answer the question asked by the lecturer, but he would give the punishment if the student made mistakes as the deterrent effect. The participant mentioned that giving of punishment and reward in the classroom could motivate students to get the point plus and become a better student. Giving of reward and punishment. He shared his experience when the participant got a reward. The lecturer gave him points when he answered the lecturer question in the classroom. For avoiding the punishment, the participant did his assignments on time. He always gathering with his friends for discussing the difficult material and improving his learning activities.

\section{Data 2}

The second participant argued that the placement of punishment and reward can be given to students in the class. The punishment must be based on large or small errors without making the offender embarrassed or the material bully of his classmates and awards given to students who have achieved or done something well and deserves appreciation. The example of giving punishment and reward in the learning process such as when students arrived late and awards given when they have done a good and worthy of appreciation. The manner of awarding is given a plus point when the students could answer the questions correctly. The participant stated that giving punishment in class could make students not repeat their mistakes again, so it would motivated students for being a good ones. Based on this statement, both of punishment and award could motivate students to learn. Point plus is award that a lecturer gave if the student obey the course rules such as answering the 


\section{Volume 2, No. 6, November 2019 pp 776-782

lecturer question, or doing the assingments on time. For avoiding the punishment, the participant did the assignment well and on time and answered questions from the lecturer.

\section{Data 3 .}

Based on the third participant's opinion, the placement of punishments and rewards in the class must be done fairly. The lecturer had to use between punishment and award appropriately. The lecturer had to make criteria when he gave a punishment or a reward to his students. For an active student, the leacturer could gave him a reward such as if his student answered the lecturer qustion actively, the lecturer would gave him a point plus as a reward;by contrast a punishment was given by a lecturer for a student who did not follow class regulations. Students' view on giving punishment are different, some of students accepted it because their awareness that they have made a mistake, as a reference became a motivation when other students are given an award. Giving punishment and appreciation could motivate students in the learning process, but it depended on each individual, whether given the punishment could make students more enthusiastic to learn again or not and it was different from the a reward because it can clearly be a reference for active enthusiasm in the learning process. The participant has not yet received a punishment, but his classmate did. They had to repeart the same subject in the next semester because they did not do the assignments given by the lecturer. Students could get a reward because they often asked and were active in that class. By following all the rules that have been determined and doing the assignment on, the participant avoided a punishment. He also followed all the lecture's rules and more active in the class for getting good grades.

\section{Data 4}

Based on the fourth participant that placement of penalties and rewards in class can be carried out but there must be an agreement on how the punishment is applied and for awarding in class is also needed because to encourage students to be more active in the learning process. Students who arrive late to class can be given a punishment for being more disciplined, and participating in class and arriving on time class is one of the causes of punishment and awards for students. Students who participate in questions such as asking or answering questions will be given an award because the student already understands what the teacher has to say is the way the teacher gives. Students' views on giving punishments and rewards in class are usually needed because to make students become more disciplined and responsible for what they have done. Punishment cannot always be a way to motivate students because it does not make motivation but rather makes pressure, and rewarding can motivate students because if students feel valued when they get it. Here, the participant has never received a sentence for being able to complete the task and be present in the study on time, and for awards once obtained when he can explain the material to be discussed then it gets a plus as an award. By coming on time and doing assignments on time this is a way to avoid getting punished, and how to get awards by reading material that will be studied first and coming on time too.

\section{Data 5}

Base in the fifth participant placement of punishment and rewards in the classroom must given to the students who repeat a mistake and do the mistake intensionaly, and for one who responsible toward duties in the classroom in the process of learning will get a reward from the teacher, the sitation that causing of giving punishment for example the students who have truancies with a reason have a another activity outside the class and the student 
not appreciate the lecture who have been present in the class different from the situation when the student is given a reward for example when the students appreciate the lecture and have responsibility on their duties in the class, when the students active to ask a question and answer the question as result will get additional score, it depend on the individu in orter to do not repeat the mistake that they have done so obviously giving a reward can motived the student an dlearning activity because the students will to compete to get that reward.

\section{Data 6}

Based on the sixtt participant punistment is something that must be exis in order to make the student have a discipline manner, get active in learning activity but it doesn't burdensome the students, a reward is very nice to apply because it can give a motivation to be better, for example, the student who proper to get a punishment when the students do not do the assignment, coming late etc. and the reward can given to the students answer the question an get additionl score, can get the B the score for the always present in every meeting, student view about the punishment is feared by the student because they wil not get a score and giving a reward can make the students have an antusition in learning activity, and giving a punishment can improve student motivation in learning activity because they will not repear a mistake it can make the student active in learning, collect assigment on time.

\section{Data 7}

The seventh participant argued that the punishment given if student did not do a task, the lecturer gave twice as many assignment as other one. Another case was if the sudents came late, the lecturer avoided them for signing the attandance class. Rewards in the classroom e obtained when student obeyed the rules, been actively in learning process and answered questions.

The participant stated when he got a punishment, it could be embarrassed moment because all of his classmates saw it. He also mentioned that giving of reward was very interesting moment because because reward was a result of the student's effort in class as his pride and could be motivation for other students.

Giving punishment gave two effects for students. Beside being a motivation for students because they tried changing for the better one, the student who got a punishment felt inteferwith mental thinking as well. For getting a reward, the partisipant said students had to do their assignment on time, respecting friends while another group presented a material in the front of class actively asking while studying and diligently.

\section{Data 8.}

The eighth participant mentioned that the placement of punishment within the class was very important because it gave as deterrent effect to students who rarely entered class, did not do assignments, or came late. The types of of punishment given by lecturer were not allowed to enter classes, fill absences and got grades. The giving of awards was very important because it made students active in class.

Appreciation was deserved by students who were active in the class and responding to the lecturer questions was the giving of plus point. Between the lecturer and student should have an agreement about how the punishment gave in the classroom, so students would be 
more careful because when the regulations applied by students, they would be more motivated to learn so that their grades increased better. Some students never got punishment because they always doing assignments on time, and participating in learning could make students avoid punishment and of course it will get an award.

Based on the data above, reward and punishment for the motivation to learn from students in English language classes at IKIP Siliwangi. Reward system usually are targeted for and used the most with students with learning and have been used traditionally in specially education class. The chance to feel that the student have some control the environment and their learning should give to the student as an options. Way to develop intrinsic motivation in students should be an important part of every teachers planning on a daily basic. And the .Punishment to increase student motivation so students will be more active in the learning process. This research showed the students had high motivated when the teacher applied punishment, it could be seen in their eagerness to try to speak English. While for scolding, the students felt unmotivated after they received it, their interest in learning English descresed after reward.

\section{Discussion}

The result of the research to find out the students perception about the implementation punishment and reward in learning activity, the indicate that help student especially in English classroom learning activities. Reward and punishment has the purpose to make students more eager to improve and enhance their achievement And present the effective or not when student get a reward and punishment in the classroom.

\section{CONCLUSION}

Based on finding of the study being aware of the perception about punishment and rewards of the learning activity and students taking more seriously about rewards and punishment, so they prepare not to get a punishment and how to get a rewards. In conclusion in this study, intended to present the relationship between punishment and negative attitude towards learning activity, the other significant of the study is that participant from same department have also different approaches towards given punishment and reward.

In offering rewards and punishment in a correct and fair manner make to be an aware accomplish to the educative etc. become more discipline, sociable, flexible, and enjoyable activity enhances student perception.

\section{ACKNOWLEDGMENTS}

In the name of Allah SWT, the beneficent, the Merciful. All praises be to Allah, Lord of the world who has given the mercy, blessing and high motivation upon the researcher in compliing this research. Peace and salutation be upon the prophet Muhammad SAW who brought me from the worse to the peace or from the bad condition to the better life. High greatest appreciation, honor, and gratitude to beloved family, friends and lecturer for supports and moral encouragements in motoving the research so that we can complete and publish our article.

\section{REFERENCES}

Balliet, D., \& Mulder, L. B. (2011). Reward, Punishment, And Cooperation : A Meta- 
Analysis. 594-615. Https://Doi.Org/10.1037/A0023489

Bishop. (2000). Classroom Interaction.

Engineering, F., Prof, J., Air, H., \& Padang, T. (2014). International Journal Of Asian Social Science The Effect Of Learning Motivation On Student 'S Productive Competencies In Vocational High School, West Sumatra Ramli Bakar Contribution / Originality. 4(6), 722-732.

Langa, C. (2014). R Ewards And Punishments Role In Teacher - Student Relationship From The Mentor' $S$ Perspective. 7(4), 7-12.

Mitchell, R., Myles, F., Marsden, E., Mitchell, R., Myles, F., Marsden, E., ... Marsden, E. (N.D.). Second Language Learning Theories.

Parmawati, A. (2018). The Study Correlation Between Reading Habit And Pronunciation Ability At The Second Grade Students Of Ikip Siliwangi. Eltin Journal, Journal of English Language Teaching In Indonesia, 6(1), 46-52.

Price, E. (1977). Communication ; Classroom Environment ; * Classroom Communication In The Classroom Are Explored. A Classroom Teacher Is Interpreted And Reacted To By The Class. Positive Feelings, Such As Teacher' S Posture, Facial Expressions And Movements. A Teacher' S Ncnverbally. Teachers, Also, Read The Nonverbal Communications Coming Teacher. Fully Comprehending The Effect Of Both Verbal And Nonverbal * Materials Not Available From Other Sources . Eric Makes Every Effort ** Reproducibility Are Often Encountered And This Affects The Qualify * * Of The Microfiche And Hardcopy Reproductions Eric Lakes Available.

Riswanto, A., Java, W., \& Entrepreneurs, S. (2017). Learning Motivation And Student Achievement: Description Analysis And Relationships Both Learning Motivation And Student Achievement: Description Analysis And Relationships Both. (July). Https://Doi.Org/10.23916/002017026010 